\title{
ANALISIS PENYERAPAN ENERGI DAN POLA DEFORMASI CRASH BOX DENGAN VARIASI SUDUT TIRUS DINDING CRASH BOX PADA UJI SIMULASI TABRAKAN ARAH FRONTAL
}

\author{
Moch. Agus Choiron, Djarot B. Darmadi, Bintang Rahmaddian Anwari \\ Jurusan Teknik Mesin, Fakultas Teknik, Universitas Brawijaya \\ Jalan M.T. Haryono no. 167, Malang 65145, Indonesia \\ Email: ra.bintang@yahoo.com
}

\begin{abstract}
Abstrak
Sistem transportasi merupakan salah satu kebutuhan yang penting untuk dipenuhi dalam mempermudah kehidupan pada zaman modern ini. Di sisi lain, meningkatnya kebutuhan akan hal tersebut juga akan ikut meningkatkan produksi kendaraan yang secara tidak langsung turut meningkatkan jumlah kecelakaan. Meninjau hal tersebut, standar keselamatan kendaraan yang lebih baik sangat dibutuhkan, salah satunya adalah crash box. Crash box merupakan sistem keamanan pasif yang digunakan untuk mengurangi tingkat keparahan kecelakaan yang dialami penumpang atau bagian kendaraan yang vital akibat tabrakan. Penelitian ini meninjau pengaruh variasi sudut tirus dinding crash box berpenampang lingkaran (circular) terhadap pola deformasi dan penyerapan energi pada uji simulasi tabrakan arah frontal. Penelitian dilakukan dengan software berbasis metode elemen hingga (MEH). Variasi yang digunakan dalam penelitian ini yaitu crash box dengan sudut tirus $(\alpha) 0,2^{\circ} ; 0,4^{\circ} ; 0,6^{\circ} ; 0,8$; dan $1,0^{\circ}$ dengan material crash box baja AISI 1340. Dari hasil penelitian diperoleh bahwa pola deformasi yang terbentuk adalah pola aksial dengan mode concertina dan campuran (concertina + diamond). Deformasi mode campuran terjadi pada crash box $t_{a} 1,6 \alpha 0,0^{\circ} ; \alpha 0,8^{\circ} ; \alpha 1,0^{\circ}$. Penyerapan energi meningkat seiring bertambah besarnya sudut tirus dinding crash box, dengan kemampuan menyerap energi terbesar pada crash box dengan sudut tirus (a) 1,0 sebesar $10823 \mathrm{~J}$. Semakin besarnya sudut tirus dinding crash box juga menunjukkan peningkatan penyerapan energi spesifik crash box.

Kata kunci: crash box, sudut tirus, tabrakan frontal, pola deformasi, penyerapan energy
\end{abstract}

\section{PENDAHULUAN}

Seiring

perkembangan sistem keamanan pada alat transportasi sangat diperlukan dikarenakan semakin meningkatnya kebutuhan akan kendaraan untuk menunjang mobilitas masyarakat. Kecelakaan lalu lintas merupakan salah satu hal yang perlu diperhatikan terkait sistem keamanan yang dikembangkan. Jumlah kecelakaan lalu lintas tahun 2013 mencapai angka 100.106 dengan jumlah korban meninggal sebanyak 26.416 [1]. Solusi dari hal tersebut adalah dengan ditambahkannya sistem keamanan yang dilakukan oleh produsen alat transportasi khususnya produsen kendaraan roda empat agar dampak yang ditimbulkan dari kecelakaan yang terjadi pada pengemudi dapat dikurangi.

Crash box merupakan sistem keamanan pasif (passive safety system) dan merupakan salah satu bagian dari crashworthy system yang digunakan untuk mengurangi tingkat keparahaan kecelakaan yang dialami penumpang atau bagian kendaraan yang vital akibat tabrakan frontal [2]. Crash box berupa struktur berdinding tipis (thin-walled structure) yang diharapkan mengalami deformasi permanen untuk menyerap energi akibat tabrakan.

Velmurugan dan Muralikannan (2009) meneliti karakteristik penyerapan energi pada crash box dengan melakukan pengujian quasi-static dari beberapa macam bentuk penampang diantaranya lingkaran (circle), persegi (square), dan persegi panjang (rectangular), masing-masing crash box memiliki ketebalan yang sama.

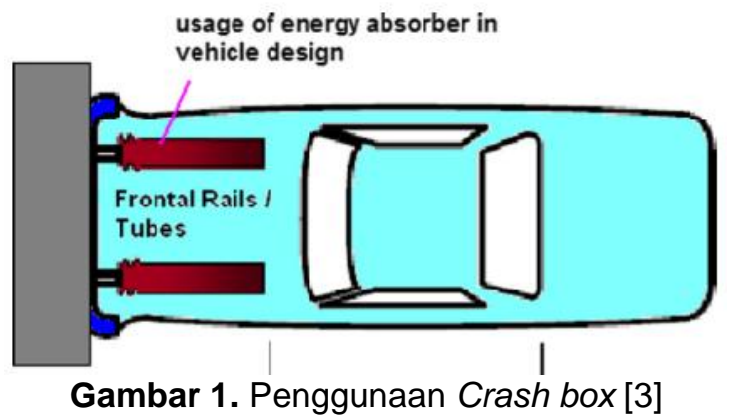

Hasil penelitian tersebut menunjukkan penyerapan energi spesifik pada penampang lingkaran (circle) lebih tinggi daripada penampang persegi (square) dan persegi panjang (rectangular) sedangkan penampang persegi (square) lebih tinggi daripada persegi panjang (rectangular) [4].

Dari penelitian yang telah disebutkan, masih belum diketahui pengaruh sudut tirus pada suatu crash box terhadap energi yang mampu diserap. Dari latar belakang tersebut, dilakukan penelitian lebih lanjut mengenai pengaruh variasi sudut tirus $(\alpha)$ pada tiap model simulasi crash box terhadap kemampuannya dalam menyerap energi juga pola deformasinya. Dipilih crash box yang berpenampang lingkaran untuk mendukung hasil penelitian sebelumnya. 


\section{METODE PENELITAN}

Metode penelitian yang digunakan dalam peneltian ini adalah eksperimental semu dengan simulasi komputer menggunakan software yang berbasis metode elemen hingga.

\section{Variabel Penelitian}

- Variabel Bebas

Variabel bebas dalam penelitian ini adalah sudut tirus $(\alpha)$ dinding crash box.

Tabel 1. Variasi Sudut Tirus

\begin{tabular}{ccc}
\hline No & $\mathrm{ta}_{\mathrm{a}}(\mathrm{mm})$ & $\alpha\left(^{\circ}\right)$ \\
\hline 1 & 1,6 & 0 \\
2 & 1,6 & 0,2 \\
3 & 1,6 & 0,4 \\
4 & 1,6 & 0,6 \\
5 & 1,6 & 0,8 \\
6 & 1,6 & 1,0 \\
\hline
\end{tabular}

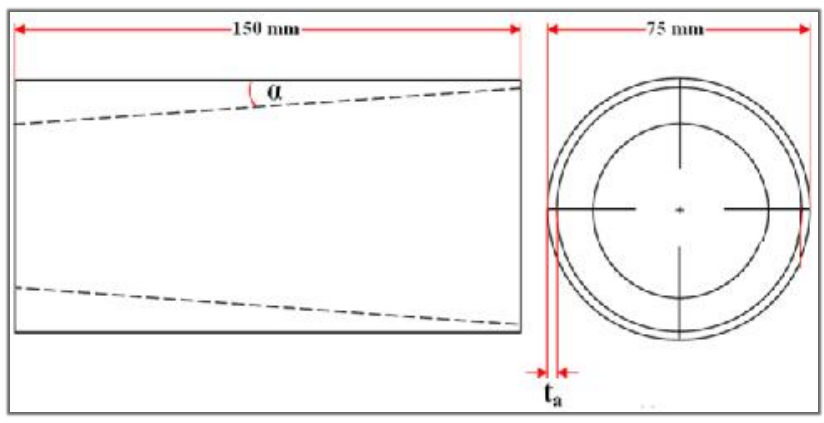

Gambar 2. Dimensi Crash Box

- Variabel Terikat

Dalam penelitian ini yang menjadi variabel terikat adalah penyerapan energi dan pola deformasi

- Variabel Terkontrol

a. Crash box berpenampang lingkaran dengan tebal dinding atas $1,6 \mathrm{~mm}$, diameter luar 75 $\mathrm{mm}$ dan panjang crash box $150 \mathrm{~mm}$.

b. Kecepatan tabrakan arah frontal $7,67 \mathrm{~m} / \mathrm{s}$.

c. Material crash box adalah baja AISI 1340.

d. Impactor dimodelkan rigid.

\section{Quasi-Static Test}

Quasi-Static Test merupakan suatu pengujian destruktif untuk menguji kemampuan suatu crash box dalam menyerap energi, prosedur pengujiannya adalah dengan cara crash box diletakkan di dasar mesin uji dengan tumpuan baja dan kemudian dikenai kompresi aksial dengan kelajuan konstan sebesar $7,67 \mathrm{~m} / \mathrm{s}$. Pengujian ini digunakan sebagai acuan validasi terhadap simulasi yang dilakukan.

\section{Data Material}

Material yang digunakan dalam penelitian ini yaitu baja AISI 1340 dengan model plastisitas bilinear isotropic hardening

Tabel 3.2 Material properties crash box Baja AISI 1340

\begin{tabular}{lc}
\hline Density $\left(\mathrm{kg} / \mathrm{m}^{3}\right)$ & 8077 \\
Poisson's Ratio & 0.29 \\
Modulus Elastisitas (GPa) & 205 \\
Yield Strength (MPa) & 266.94 \\
Shear Modulus (GPa) & 76 \\
\hline
\end{tabular}

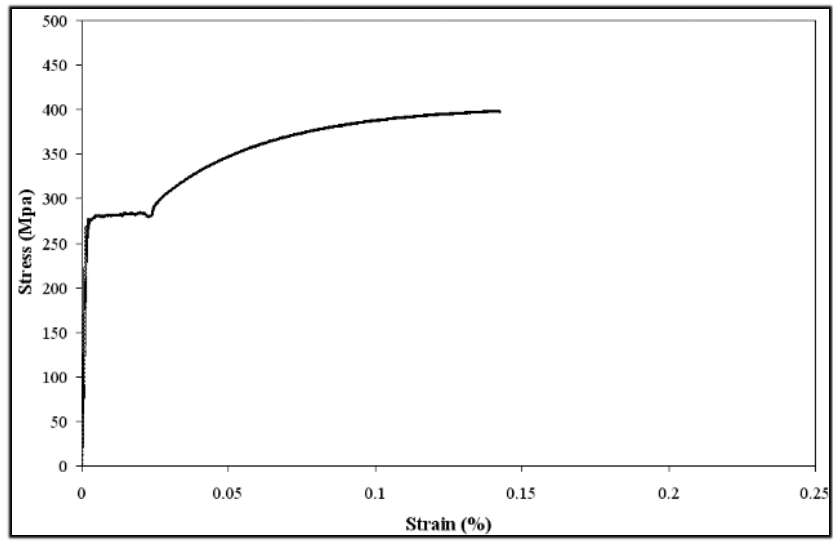

Gambar 3. Diagram Tegangan-Regangan Plastis Baja AISI 1340

\section{Meshing}

Meshing adalah proses membagi obyek yang semula adalah elemen tak terhingga (infinite) menjadi elemen-elemen tertentu dengan jumlah yang berhingga (finite). Dalam penelitian ini digunakan meshing secara otomatis dengan jenis elemen explicit dan tipe elemen brick 8 node dengan ukuran $1,3 \mathrm{~mm}$ untuk crash box dan elemen solid heksahedron dengan ukuran $30 \mathrm{~mm}$ untuk impactor.

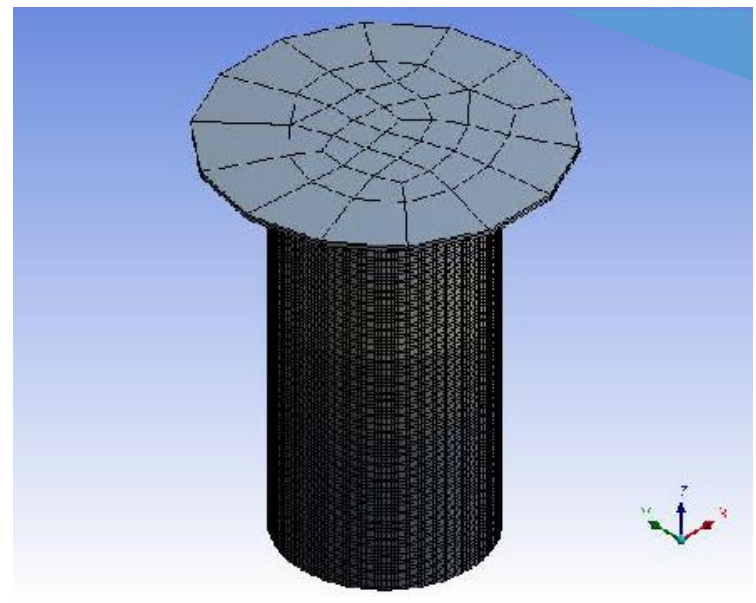

Gambar 4. Meshing pada Software MEH

\section{Simulasi dan Pembebanan}

Proses simulasi dalam penelitian ini dimulai dengan keadaan awal impactor dan crash box 
menempel. Impactor dimodelkan sebagai rigid body sedangkan crash box sebagai flexible body. Tumpuan jenis fixed support diposisikan pada bagian bawah crash box. Dalam simulasi, impactor akan bergerak menumbuk crash box dengan kecepatan $7,67 \mathrm{~m} / \mathrm{s}$ searah aksial terhadap crash box. Tumbukan ini akan mengakibatkan crash box mengalami deformasi. Simulasi dilakukan sampai waktu $1 \times 10^{-2}$ detik.
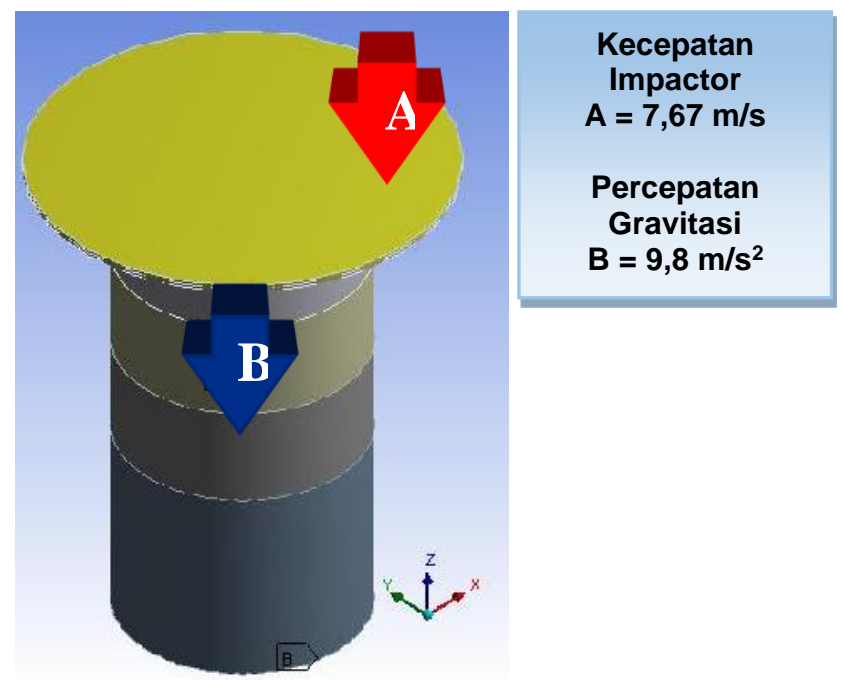

Gambar 5. Pemodelan pada Software MEH

\section{Verifikasi Penelitian}

Verifikasi penelitian dilakukan pada penelitian Velmurugan et. al. (2009) dengan crash box berpenampang lingkaran dengan dimensi sebagai berikut:

$\begin{array}{ll}\text { Diameter } & =75 \mathrm{~mm} \\ \text { Panjang } & =150 \mathrm{~mm} \\ \text { Ketebalan } & =1.6 \mathrm{~mm} \\ \text { Material } & =\text { Baja AISI } 1340\end{array}$

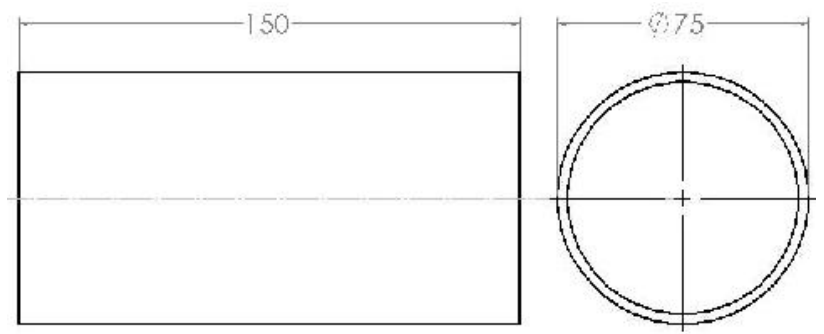

Gambar 6. Crash Box Verifikasi

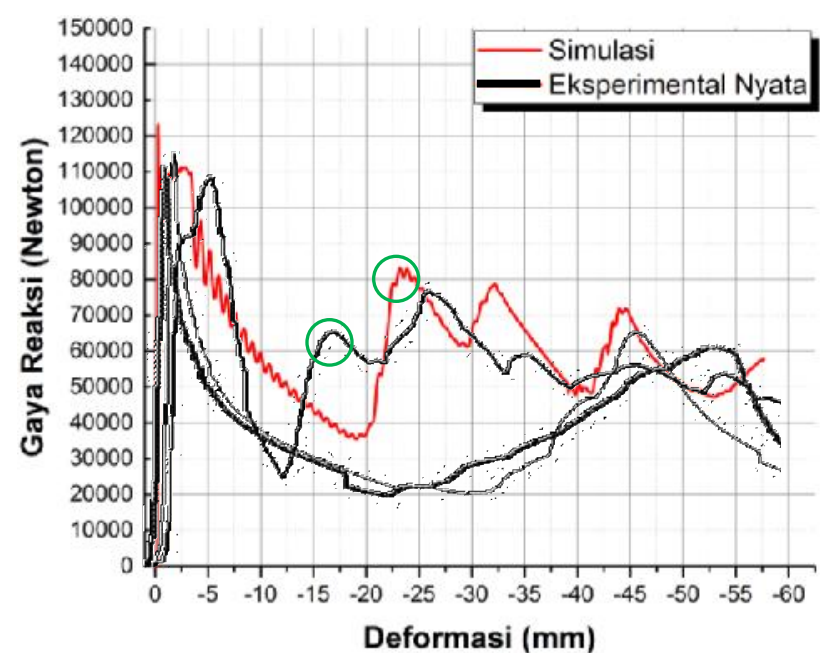

Gambar 7. Grafik Perbandingan Hasil Simulasi dan Eksperimen

Tabel 4. Data Perbandingan Hasil Simulasi dan Eksperimen

\begin{tabular}{cc}
\hline Simulasi & Eksperimental Nyata \\
\hline Gaya Rata-Rata: & Gaya Rata-Rata: \\
$\mathbf{5 7 , 3 3 5 ~ k N}$ & $\mathbf{5 5} \mathbf{~ k N}$ \\
\hline Energi yang Diserap: & Energi yang Diserap: \\
$\mathbf{3 4 4 0 , 1}$ Joule & $\mathbf{3 3 0 6 , 5 7}$ Joule \\
\hline
\end{tabular}

- Gaya Rata-Rataerror (\%)

$$
\frac{57,335-55}{57,335} \times 100 \%=4,073 \%
$$

- Energi error $\%)$

$$
\frac{3440,1-3306,57}{3440,1} \times 100 \%=3,882 \%
$$

\section{PEMBAHASAN}

Data Hasil Simulasi

Diperoleh hasil berupa pola deformasi yang terjadi dan penyerapan energi pada crash box. Data penyerapan energi crash box dengan variasi sudut tirus dinding $(\alpha)$ ditunjukkan pada tabel 5.

Tabel 5. Data Hasil Simulasi

\begin{tabular}{cccc}
\hline No & $\mathrm{ta}_{\mathrm{a}}(\mathrm{mm})$ & $\alpha\left(^{\circ}\right)$ & Penyerapan Energi $(\mathrm{J})$ \\
\hline 1 & 1,6 & 0 & 4987,41 \\
2 & 1,6 & 0,2 & 5706,74 \\
3 & 1,6 & 0,4 & 6744,45 \\
4 & 1,6 & 0,6 & 8035,45 \\
5 & 1,6 & 0,8 & 9421,21 \\
6 & 1,6 & 1,0 & 10822,96 \\
\hline
\end{tabular}


Grafik gaya reaksi - deformasi yang digunakan untuk mengukur besar penyerapan energi diperoleh dengan cara menggabungkan grafik deformasi terhadap waktu dan gaya reaksi terhadap waktu yang diperoleh dari software $\mathrm{MEH}$.

\section{Pola Deformasi Crash Box}

Secara umum pola deformasi yang terjadi untuk seluruh crash box telah sesuai dengan yang dikemukakan oleh Velmurugan dan Muralikannan (2009) dalam penelitiannya bahwa pada axially loaded test pola deformasi crash box bisa terjadi dalam dua mode yaitu mode aksisimetris atau biasa disebut concertina dan mode diamond dimana lipatan-lipatan transversal dan longitudinal terbentuk. Pada penelitian ini, setiap crash box mengalami pola deformasi berupa mode concertina. Deformasi mode diamond hanya terjadi pada crash box tanpa ketirusan dinding. Apabila suatu model crash box telah mengalami deformasi mode diamond maka deformasinya tidak akan bisa kembali ke mode concertina.

Terlihat pada tabel 6 bahwa pada crash box ta 1,6 a $0,0^{\circ}$; a $0,8^{\circ}$; a $1,0^{\circ}$ memiliki mode diamond pada deformasinya. Hal tersebut bisa dikarenakan ketidakseimbangan crash box dalam menerima beban yang disebabkan oleh adanya bagian yang mengalami pecah, sehingga bagian yang mengalami pecah yang lebih sedikit cenderung lebih dapat mempertahankan posisinya terhadap deformasi.

\section{Penyerapan Energi}

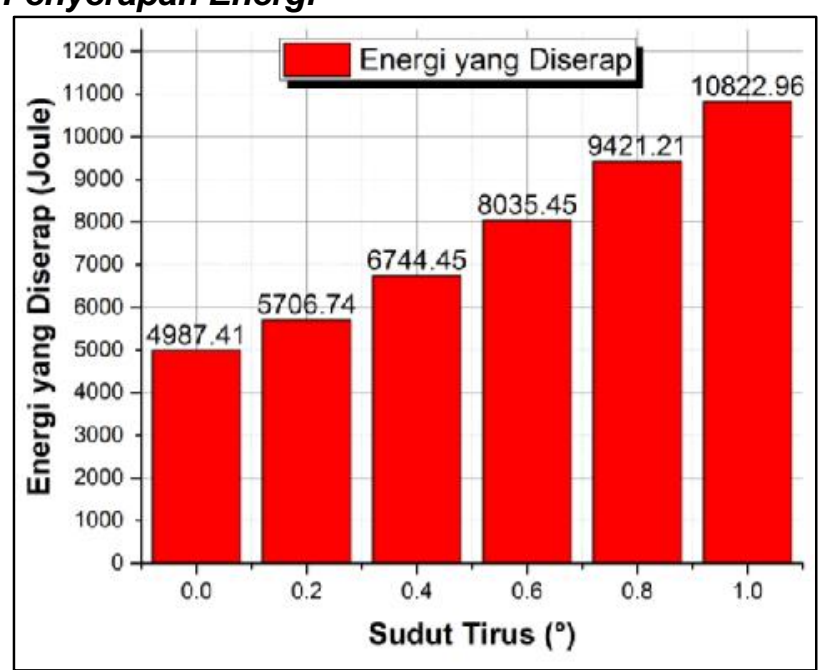

Gambar 8. Grafik Hubungan Penyerapan Energi Crash Box Dan Besar Sudut Tirus

Dari hasil simulasi yang ditunjukkan oleh Tabel 5, crash box dengan tebal dinding 1,6 $\mathrm{mm}$ tanpa ketirusan dinding memiliki penyerapan energi sebesar 4987,41 J. Dari gambar 8 dapat diketahui bahwa semakin besar sudut tirus dinding crash box maka kemampuan penyerapan energi akan mengalami peningkatan.

Hal ini dikarenakan semakin besar sudut tirus dinding crash box maka akan membuat kekakuan dari crash box tersebut semakin meningkat. Crash box yang kaku akan memberikan gaya reaksi yang lebih tinggi sehingga energi regangannya semakin tinggi sesuai persamaan energi regangan [5]:

$$
\mathrm{U}=\int_{0}^{\delta} \mathrm{P}(\delta) \mathrm{d} \delta
$$



Semakin besar sudut tirus dinding crash box maka akan semakin besar pula inersianya. Dengan semakin besarnya inersia suatu crash box akan semakin memperbesar $\mathrm{P}_{c r}$ crash box pada awal buckling sesuai dengan rumus [6]:

$$
P_{c r}=\frac{\pi^{2} E I}{4 L^{2}}
$$

Dengan :

$$
\begin{array}{ll}
P_{c r} & =\text { Beban kritis }(\mathrm{N}) \\
E & =\text { Modulus Elastisitas }(\mathrm{Pa}) \\
I & =\text { Momen inersia penampang }\left(\mathrm{m}^{4}\right) \\
L & =\text { Panjang } \operatorname{kolom}(\mathrm{m})
\end{array}
$$

\section{Penyerapan Energi Spesifik Crash Box}

Penyerapan energi spesifik (specific energy absorption) adalah ukuran yang menyatakan energi yang diserap oleh crash box per satuan massa. Besaran ini perlu dihitung karena dalam penelitian ini peningkatan sudut tirus dinding akan mempengaruhi massa crash box. Penghitungan penyerapan energi spesifik crash box dimaksudkan untuk mengetahui tingkat keefektifan sudut tirus dinding crash box.

Tabel 7. Massa Tiap Crash Box

\begin{tabular}{cccc}
\hline No & $\mathrm{ta}_{\mathrm{a}}(\mathrm{mm})$ & $\alpha\left(^{\circ}\right)$ & Massa $(\mathrm{kg})$ \\
\hline 1 & 1,6 & 0 & 0,2682 \\
2 & 1,6 & 0,2 & 0,2939 \\
3 & 1,6 & 0,4 & 0,3194 \\
4 & 1,6 & 0,6 & 0,3448 \\
5 & 1,6 & 0,8 & 0,3700 \\
6 & 1,6 & 1,0 & 0,3951 \\
\hline
\end{tabular}

Tabel 8. Penyerapan energi spesifik

\begin{tabular}{ccccc}
\hline No & $\begin{array}{c}\mathrm{ta}_{\mathrm{a}} \\
(\mathrm{mm})\end{array}$ & $\begin{array}{c}\alpha \\
\left(^{\circ}\right)\end{array}$ & $\begin{array}{c}\text { Energi } \\
(\text { Joule })\end{array}$ & $\begin{array}{c}\text { Energi } \\
\text { Spesifik } \\
(\mathrm{J} / \mathrm{kg})\end{array}$ \\
\hline 1 & 1,6 & 0 & 4987,41 & 18595,86 \\
2 & 1,6 & 0,2 & 5706,74 & 19417,95 \\
3 & 1,6 & 0,4 & 6744,45 & 21115,34 \\
4 & 1,6 & 0,6 & 8035,45 & 23305,35 \\
5 & 1,6 & 0,8 & 9421,21 & 25461,35 \\
6 & 1,6 & 1,0 & 10822,96 & 27392,27 \\
\hline
\end{tabular}


Tabel 6. Mode deformasi yang terbentuk

\begin{tabular}{|c|c|c|c|}
\hline No & $\mathrm{t}_{\mathrm{a}}(\mathrm{mm})$ & $\alpha\left({ }^{\circ}\right)$ & $\begin{array}{l}\text { Keterangan gambar (mode concertina dilingkari kuning } \\
\text { dan mode diamond dilingkari merah) }\end{array}$ \\
\hline 1 & 1,6 & 0,0 & \\
\hline 2 & 1,6 & 0,2 & \\
\hline 3 & 1,6 & 0,4 & \\
\hline 4 & 1,6 & 0,6 & \\
\hline 5 & 1,6 & 0,8 & \\
\hline
\end{tabular}




$\begin{array}{lll}\text { No } \quad t_{\mathrm{a}}(\mathrm{mm}) & \alpha\left(^{\circ}\right) & \begin{array}{c}\text { Keterangan gambar (mode concertina dilingkari kun } \\ \text { dan mode diamond dilingkari merah) }\end{array} \\ 6 \quad 1,6 & 1,0\end{array}$

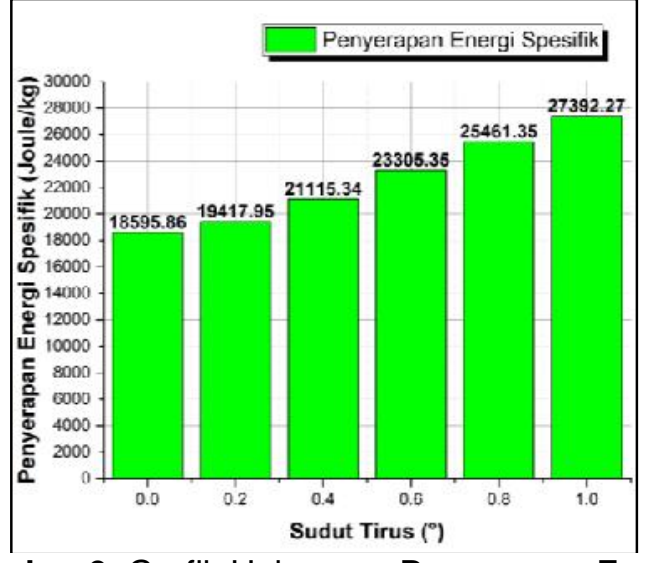

Gambar 9. Grafik Hubungan Penyerapan Energi Spesifik terhadap Sudut Tirus

Pada gambar 9 yang menunjukkan grafik hubungan penyerapan energi spesifik terhadap sudut tirus, dapat dilihat bahwa seiring meningkatnya sudut tirus maka penyerapan energi spesifiknya juga akan semakin meningkat disebabkan oleh rentang kenaikan penyerapan energi lebih besar dibandingkan rentang kenaikan massa. Hal tersebut menunjukkan bahwa semakin besar sudut tirus suatu crash box maka akan semakin efektif pula dalam menyerap energi.

\section{Grafik Hubungan Gaya Reaksi - Deformasi}

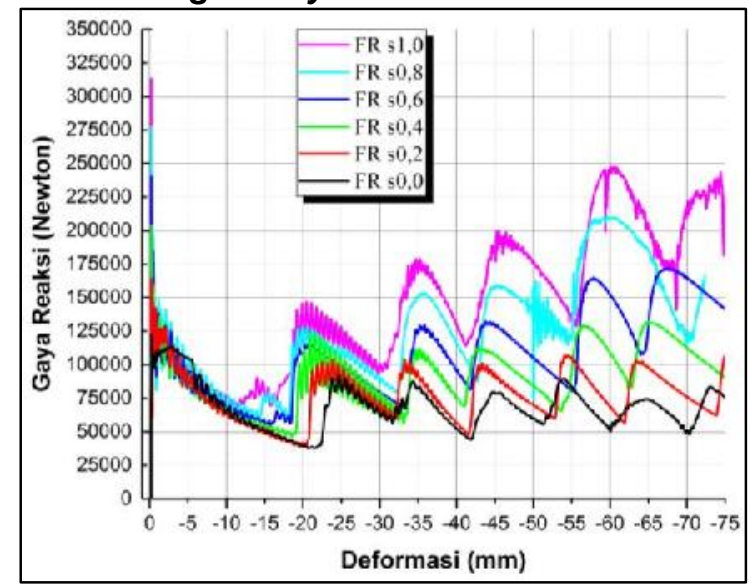

Gambar 10. Grafik gaya reaksi - deformasi crash box dengan variasi sudut tirus dinding
Pada grafik hubungan gaya reaksi - deformasi dapat dianalisis berdasarkan luas daerah dibawah kurva masing-masing crash box. Luas daerah di bawah kurva menunjukkan usaha yang dilakukan oleh beban pada crash box. Usaha dari beban itu saat dikenakan pada crash box diubah menjadi energi regangan. Dengan asumsi bahwa keseluruhan energi kinetik terkonversi menjadi energi regangan, maka dapat disimpulkan bahwa usaha beban sama dengan energi regangan pada material crash box.

Pada grafik terlihat bahwa semakin besar sudut tirus suatu crash box maka gaya reaksi puncak yang dialami juga akan semakin besar. Pada crash box tanpa ketirusan dinding memiliki gaya reaksi puncak sebesar $122 \mathrm{kN}$ sedangkan pada crash box dengan sudut tirus $1,0^{\circ}$ gaya reaksi puncaknya mencapai $312 \mathrm{kN}$.

Berdasarkan hasil pengukuran luas daerah dibawah grafik gaya reaksi - deformasi menggunakan software $C A D$ diperoleh hasil seperti pada tabel 9 berikut. Digunakan faktor skala yang merupakan hasil perbandingan dari nilai energi dengan luas grafik dalam gambar $C A D$ yaitu sebesar $0,33 \mathrm{~J} / \mathrm{mm}^{2}$.

Tabel 9. Hasil pengukuran luasan

\begin{tabular}{ccccc}
\hline No & $\begin{array}{c}\mathrm{ta}_{\mathrm{a}} \\
(\mathrm{mm})\end{array}$ & $\begin{array}{c}\alpha \\
\left({ }^{\circ}\right)\end{array}$ & $\begin{array}{c}\text { Luas } \\
\left(\mathrm{mm}^{2}\right)\end{array}$ & $\begin{array}{c}\text { Penyerapan } \\
\text { Energi } \\
(\text { Joule })\end{array}$ \\
\hline 1 & 1,6 & 0,0 & 14962,2 & 4987,41 \\
2 & 1,6 & 0,2 & 17120,2 & 5706,74 \\
3 & 1,6 & 0,4 & 20233,4 & 6744,45 \\
4 & 1,6 & 0,6 & 24106,4 & 8035,45 \\
5 & 1,6 & 0,8 & 28263,6 & 9421,21 \\
6 & 1,6 & 1,0 & 32468,9 & 10822,96 \\
\hline
\end{tabular}

Luas daerah di bawah grafik semakin luas seiring bertambahnya sudut tirus dinding crash box dengan nilai tertinggi pada crash box dengan sudut tirus dinding $1,0^{\circ}$. 


\section{Besar Penyerapan Energi Crash Box dari Ketinggian Tertentu}

Pada bagian ini dibahas mengenai besar penyerapan energi crash box dari ketinggian tertentu. Dimana sebelum simulasi dijalankan, pada model crash box diberi surface analisa pada ketinggian tertentu pada suatu crash box untuk mengetahui besarnya gaya reaksi dan deformasi yang terjadinya dimulai pada letak surface analisa tersebut. Letak surface analisa tersebut ditunjukkan pada gambar 11 berikut:

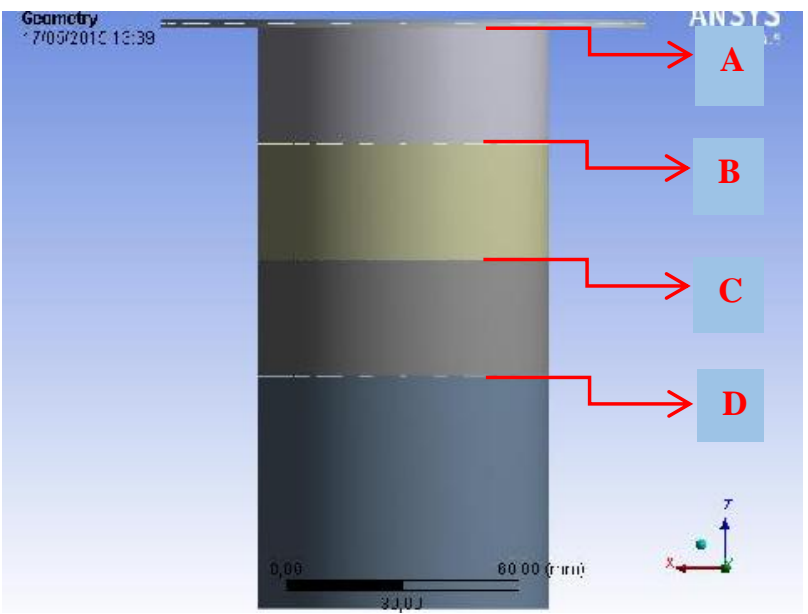

Gambar 11. Surface Analisa pada Ketinggian Tertentu pada Suatu Crash Box. (A: Ujung, B: $30 \mathrm{~mm}$ dari A, C: $60 \mathrm{~mm}$ dari $A, D: 90 \mathrm{~mm}$ dari $A$ )

Deformasi yang terjadi dan letak surface analisa sebelum deformasi pada crash box ta $1,6 \propto 0,0^{\circ}$ dan crash box ta 1,6 a $0,6^{\circ}$ ditunjukkan oleh gambar 12 berikut:

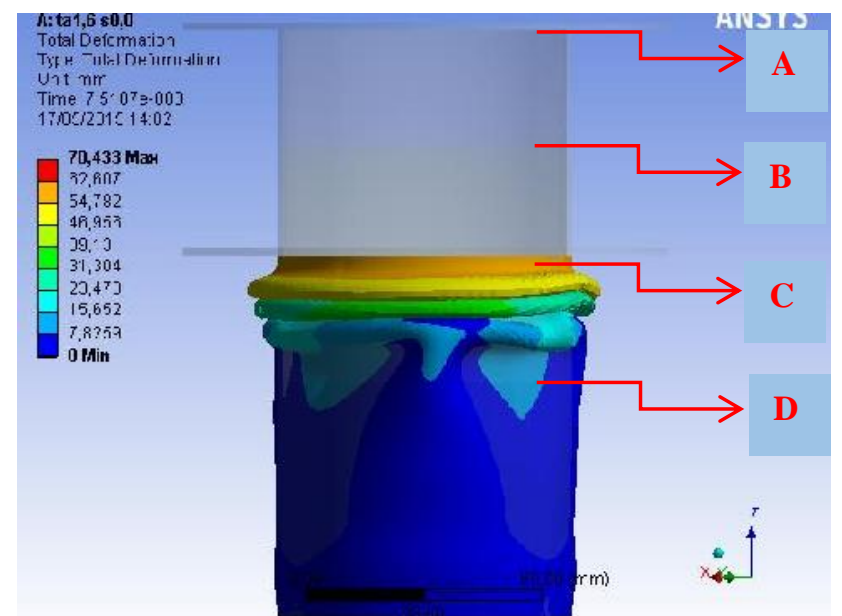

Gambar 12. Deformasi yang terjadi dan letak surface analisa sebelum deformasi pada crash box $t_{a} 1,6 \propto 0,0^{\circ}$

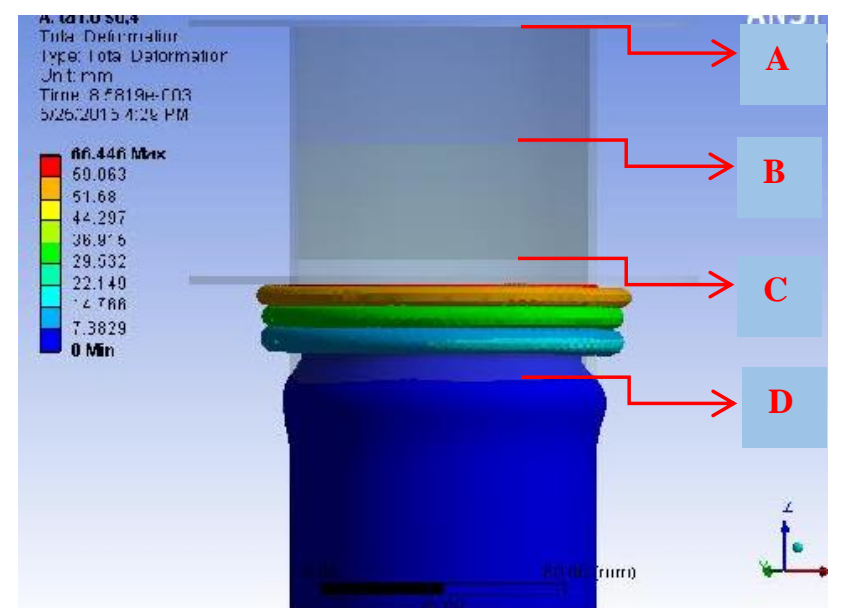

Gambar 13. Deformasi yang terjadi dan letak surface analisa sebelum deformasi pada crash box ta $1,6 \propto 0,6^{\circ}$

Gaya-gaya reaksi dan deformasi yang terjadi pada setiap surface analisa digambarkan oleh grafik pada Gambar 14 dan Gambar 15 berikut:

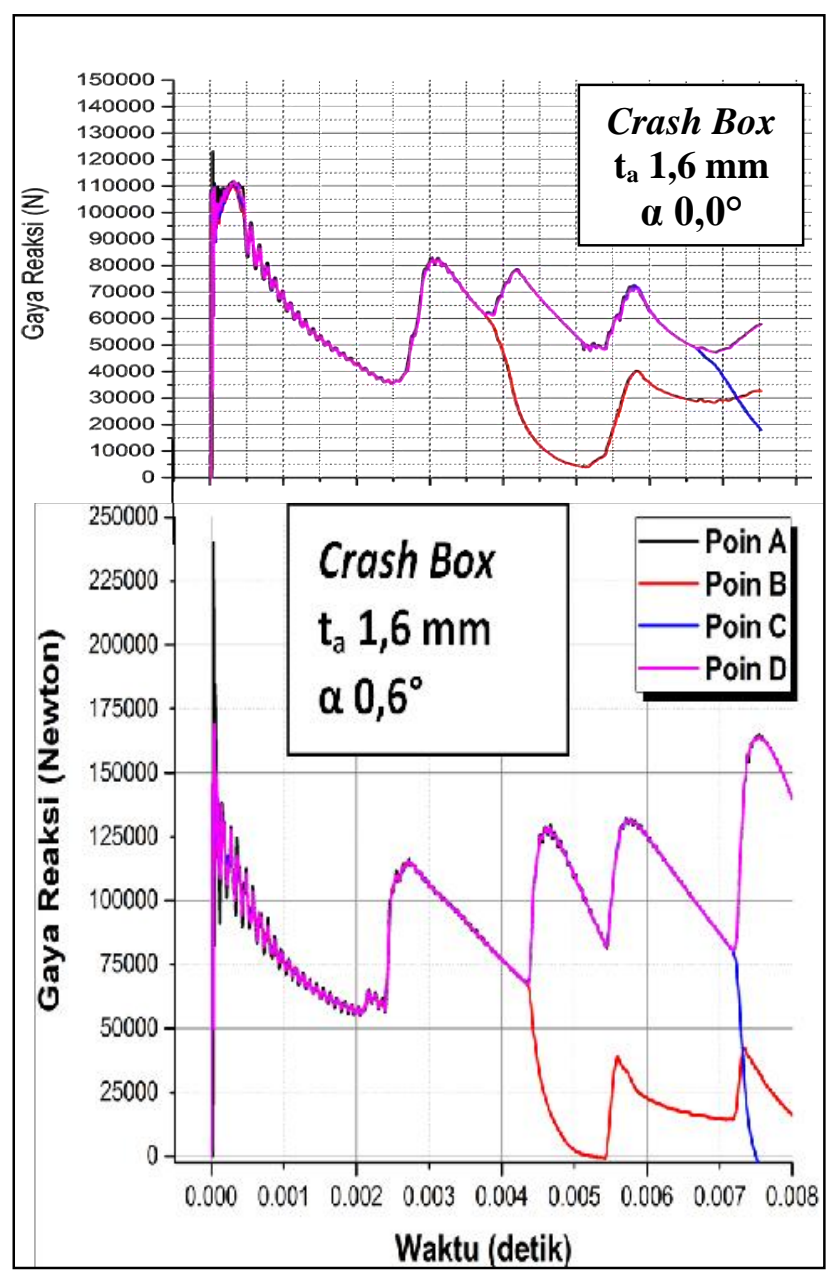

Gambar 14. Gaya-gaya reaksi yang terjadi dari setiap surface analisa 


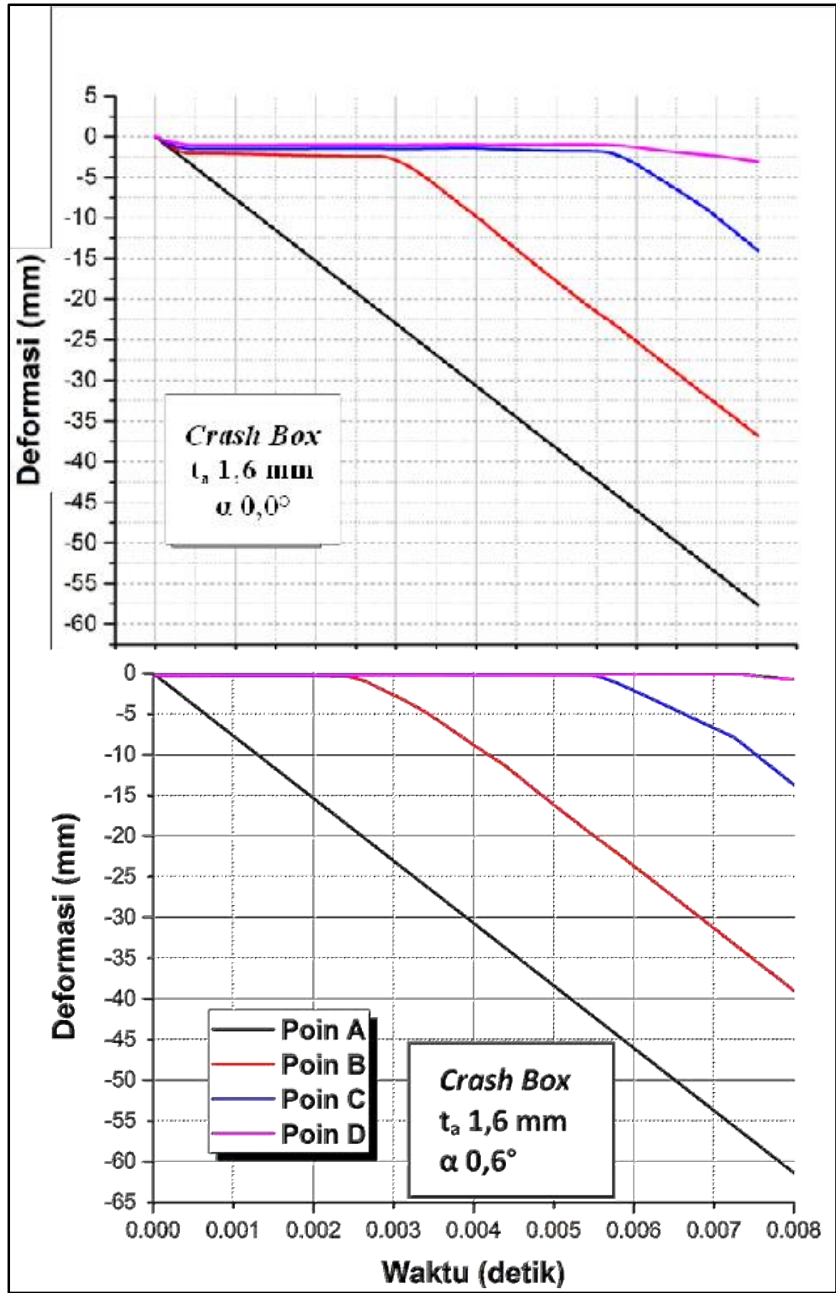

Gambar 15. Deformasi yang terjadi dari setiap surface analisa

Penggabungan antara kedua grafik diatas yaitu ketika gaya reaksi diposisikan pada sumbu y dan deformasi diposisikan pada sumbu x maka akan dihasilkan grafik gaya reaksi - deformasi dimana luas daerah dibawah kurva grafik tersebut merupakan besar energi yang diserap oleh crash box. Sehingga dapat diketahui besarnya penyerapan energi suatu crash box yang dimulai pada surface analisa pada ketinggian tertentu yang telah ditentukan. Surface analisa pertama yaitu $A$ yang terletak pada ujung crash box yang memiliki kontak langsung dengan impactor, B terletak sejauh $30 \mathrm{~mm}$ dari A, C terletak sejauh $60 \mathrm{~mm}$ dari $A$, dan $D$ terletak sejauh $90 \mathrm{~mm}$ dari A. Grafik gaya reaksi - deformasi yang dimaksud ditunjukkan oleh Gambar 16.

Dari Gambar 16 dapat dilihat bahwa penyerapan energi paling besar terjadi pada bagian paling atas crash box dan semakin ke bawah bagian crash box semakin kecil peranannya dalam menyerap energi. Hal tersebut dikarenakan energi dari impactor diserap oleh crash box menjadi energi regangan melalui deformasi yang paling banyak terjadi pada bagian atas crash box. Rincian energi yang diserap oleh crash box dari surface analisa A, B, C, dan D disajikan pada Tabel 10.

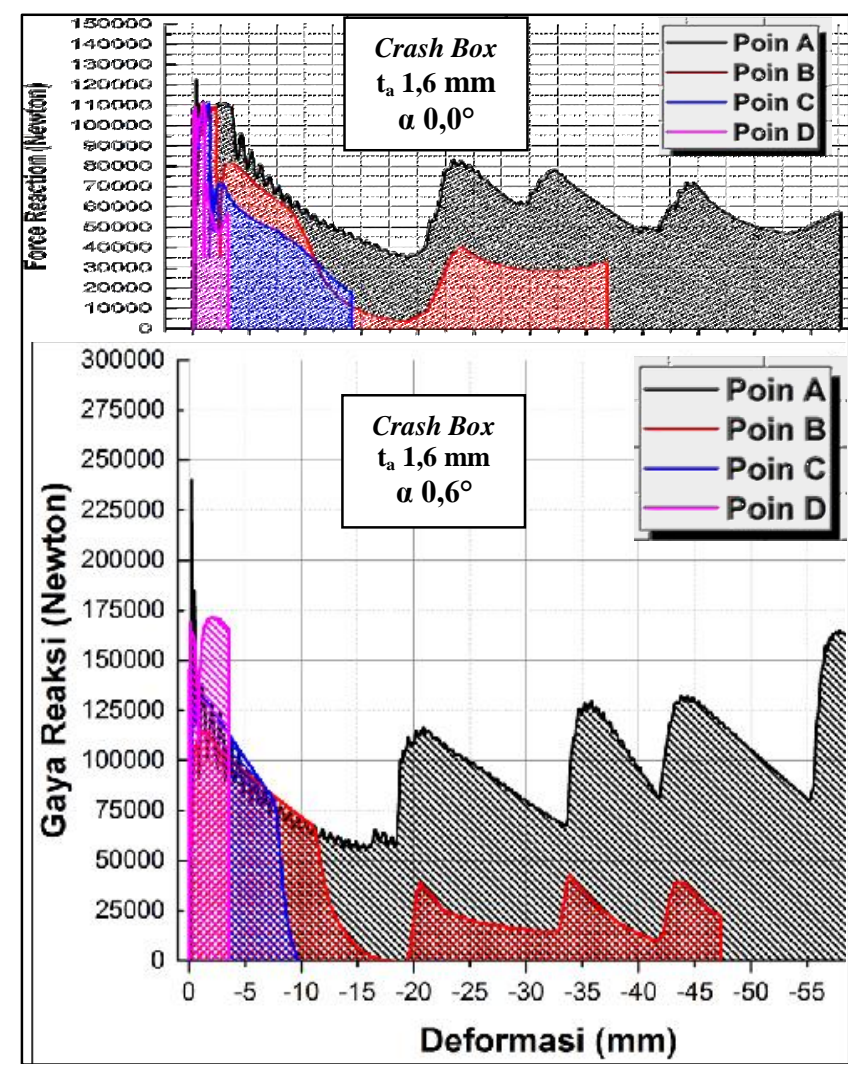

Gambar 16. Kurva gaya reaksi - deformasi dari setiap surface analisa

Tabel 10. Penyerapan energi dari setiap surface analisa

\begin{tabular}{ccc}
\hline & \multicolumn{2}{c}{ Penyerapan Energi $(\mathrm{J})$} \\
\cline { 2 - 3 } Surface & Crash Box & Crash Box \\
Analisa & ta $1,6 \mathrm{~mm}$ & ta $1,6 \mathrm{~mm}$ \\
& $\alpha 0,0^{\circ}$ & $\alpha 0,6^{\circ}$ \\
\hline A & 3587.94 & 6562,06 \\
B & 1395.36 & 1939.3 \\
C & 729.66 & 907,17 \\
D & 219.36 & 630,13 \\
\hline
\end{tabular}

Pada Gambar 14 ditunjukkan bahwa pada waktu mencapai 0,003 dan 0,006 detik terjadi penurunan drastis pada gaya reaksi yang dialami oleh surface analisa B dan C pada crash box ta 1,6 $\mathrm{mm} \alpha 0,0^{\circ}$. Hal yang sama terjadi pada crash box ta $1,6 \mathrm{~mm} \propto 0,6^{\circ}$ ketika waktu mencapai 0,0025 dan 0,0055 detik. Hal tersebut dikarenakan pada surface analisa B dan C pada waktu tersebut mengalami buckling yang membuat gaya reaksi yang diterima menjadi berkurang.

\section{KESIMPULAN}

Berdasarkan analisis yang telah dilakukan dalam penelitian ini dapat disimpulkan bahwa pola deformasi yang terbentuk pada crash box circular dengan ketirusan dinding dalam uji tabrakan arah frontal adalah pola buckling aksial ditunjukkan dengan adanya lipatan-lipatan pada dinding crash box yang cenderung aksisimetris dengan mode concertina. Semakin besar sudut tirus dinding crash 
box maka semakin besar pula energi yang mampu diserap, yaitu pada crash box dengan tebal ( $\left.t_{a}\right)$ 1,6 $\mathrm{mm}$ dan sudut tirus $(\alpha) 1,0^{\circ}$ mampu menyerap energi sebesar 10822.963 Joule. Crash box dengan tebal (ta) 1,6 mm dan sudut tirus (a) 1,0 merupakan crash box dengan ketirusan dinding yang memiliki penyerapan energi spesifik yang paling baik dengan nilai sebesar 27392,27 Joule/kg.

\section{DAFTAR PUSTAKA}

[1] Badan Pusat Statistik. 2014. Jumlah Kecelakaan, Korban Mati, Luka Berat, Luka Ringan, dan Kerugian Materi yang Diderita Tahun 19922013. Indonesia : Badan Pusat Statistik.

[2] Najmi Yahya Talib (2013),. Analisis Penyerapan Energi dan Deformasi Crash Box dengan Variasi Diameter dan Panjang Pada Uji Dropped Weight Impact. Jurnal Rekayasa Mesin.
[3] F. Tarlochan, F. Samer, A.M.S. Hamouda, S. Ramesh, K. Khalid (2013), Design of Thin Wall Structures for Energy Absorption Application: Enhancement of Crashworthiness Due to Axial and Oblique Impact Forces, Journal of ThinWalled Structures, 71: 7-17.

[4] Velmurugan, R. and R. Muralikannan (2009), Energy Absorption Characteristics of Annealed Steel Tubes of Various Cross Section in Static and Dynamic Loading. Latin American Journal of Solid and Structures, vol. 6, pp. 385-412.

[5] Richard G. Budynas (1977), Advanced Strength and Applied Stress Analysis. McGraw Hill, Tokyo.

[6] J.M. Gere (2004), Mechanics of Materials, $6^{\text {th }}$ Edition. Thomson Learning, Inc., New York. 